\title{
Transitional Justice and Democracy in Uganda: Between Impetus and Instrumentalisation
}

\author{
Valérie Arnould \\ Postdoctoral Research Fellow, School of Business and Law, University of East London \\ Published in Journal of Eastern African Studies 9:3 (2015), pp.354-374
}

\begin{abstract}
While claims abound regarding transitional justice's importance for democracy building in transitioning countries, empirical investigations of these remain limited or have produced contradictory findings. This article seeks to contribute to these debates by investigating the relationship between transitional justice and democratic institutionbuilding in Uganda - looking in particular at the rule of law, the security forces and participation. It does so by exploring the causal mechanisms linking transitional justice to democracy, that is, the means through which transitional justice exerts its impact. Transitional justice is widely expected to impact democratic institution-building through three mechanisms: (de)legitimation, reform, and empowerment. However, this article finds that in Uganda, transitional justice's impact through these is more circumscribed than has so far been assumed, and that it sometimes impacts democratic institutionbuilding negatively. The Ugandan experience furthermore suggests that in contexts of armed conflict and a hybrid regime, expectations about the extent to which transitional justice can support democratic institution-building should be lowered.
\end{abstract}

Keywords: Uganda, transitional justice impact, democracy, ICC, truth commission, amnesties

The growing recourse to transitional justice measures to address legacies of mass human rights abuses has provoked an intense debate about their effectiveness. Now that transitional justice has moved out of its infancy - a period marked by high hopes and bold, some would say idealistic, claims about its ability to help transitional countries 
build stable and peaceful polities - scholars and practitioners are increasingly contesting its political and societal effects. Whereas for some transitional justice has the ability to radically overhaul political processes and societies, others question whether these claims are realistic and effective. A major challenge is that views on transitional justice's effects are often normatively rather than empirically founded. As Thoms, Ron, and Paris observed, "it is striking that so many commentators have expressed such strong positions on the basis of so little reliable evidence". 1

Claims about transitional justice's impact on democracy are particularly contentious. At its inception, transitional justice was conceived as a measure to accompany and support transitions towards democracy, by contributing to building a new polity based on the rule of law and human rights. Although transitional justice is no longer confined to transitions out of authoritarian rule and many transitions did not in fact see the emergence of democracy, the assumption that transitional justice is meant to ensure that countries undergoing a transition move towards democracy, rather than another form of governance, remains widespread. Yet, in practice, we know very little about whether transitional justice contributes to democracy - and if it does, how so.

The present article aims to contribute to these debates by exploring the relationship between transitional justice and democratic institution-building in Uganda, focusing in particular on the causal processes linking both. Uganda offers an interesting case study because it has a mixed record in terms of democratic development since its attempted transition in $1986 .{ }^{2}$ Uganda not only evolved into a hybrid regime but it also continued to experience armed conflict in parts of the country, thus creating an environment that could be labelled as an incomplete or aborted transition (some would even say a 'non transition'). The fact that the democratic transition largely failed in Uganda does not make it any less interesting to explore how transitional justice 
interacted with (non-) democratic transformations in the country. Uganda offers an opportunity to investigate an intriguing instance of democratic failure with transitional justice. Moreover, transitional justice measures were implemented at various periods in time: some closely following the regime transition, while others well after regime consolidation and while armed conflict was ongoing, or while peace negotiations were underway - thus combining elements of 'transitional justice', 'in transition justice' and 'post-transition justice'. Uganda thus represents a case of non-linear transition, which can be expected to produce particular challenges for transitional justice impact.

I will begin by critically reviewing the existing literature on the relationship between democracy and transitional justice, following which I present three commonly assumed (though undertheorised) pathways of transitional justice impact. After an overview of Uganda's democratic trajectory, the empirical section investigates to what extent the claimed pathways of impact are observed in the Ugandan case, and to what effect. To this end, it looks at three state-led transitional justice measures: trials, commissions of inquiry, and amnesties. The paper finds that transitional justice's impact is more circumscribed than has so far been assumed by the literature, and that it sometimes impacts democratic institution-building negatively. The case study further suggests that in a context where the political will for democratisation is limited and a hybrid regime is firmly entrenched, expectations about the extent to which transitional justice can support democratic institution-building should be lowered.

\section{Transitional Justice and Democracy}

Both transitional justice and democracy are complex and multifaceted processes, making it difficult to unravel and conceptualise their relationship. Not only is democracy an amorphous concept subject to a variety of interpretations, but there is also 
no definite agreement on which factors cause democracy or help explain why certain countries achieve democratic 'success' while others do not. In this context, determining if transitional justice is a factor supporting democratic development constitutes a formidable task. Within the existing literature, there are broadly three views about the nature of their relationship: transitional justice as a necessary condition for democracy, as harmful to democracy, and as dependent on democratic progress.

According to some, transitional justice is necessary for democracy because it strengthens the rule of law, deters human rights abuses, promotes reconciliation and prevents vigilante justice. ${ }^{3}$ By reshaping institutions, actors, identities and social behaviour - that is, by redefining the social and political order - transitional justice has the potential to positively contribute to democracy. It is purported to do so in a variety of ways, ranging from restoring relations between previously antagonistic groups; encouraging open debates about the past and thereby constructing a new inclusive political and social memory; to restoring citizen's trust in public institutions; and providing an opportunity for new leaders to signal a break with past non-democratic practices.

More critical scholars however caution that transitional justice often fails to deliver on its promises of improved human rights protection and reconciliation, and sometimes even risks destabilising democratisation processes, increasing human rights abuses, heightening political and societal tensions, and hampering negotiations for political transitions. ${ }^{4}$ Trials and truth commissions may fail to contribute to democracy through truth telling as they sometimes produce distorted or partial historical understandings of the past, due to either procedural constraints or political instrumentalisation by elites. ${ }^{5}$ In turn, truth commissions and memorials can revive or 
aggravate societal tensions, while their lack of punishment of perpetrators may provoke resentment, vigilante justice, and weaken trust in public institutions.

A third approach flips around the relationship between transitional justice and democracy, by arguing that transitional justice's effectiveness depends on the presence of a minimum level of democracy in a country. For instance, the existence of a vibrant civil society - a key marker of democratic quality - has been found to play an important role in promoting transitional justice. ${ }^{6}$ It is also argued that trials and truth commissions are more likely to take place and be effective if a functioning judiciary and democratic culture are in place. ${ }^{7}$ Transitional justice is thus seen as reflecting rather than causing democratic developments. A central prescription drawn from this is the importance of the timing of transitional justice processes and the need, where necessary, to postpone transitional justice until a country has achieved some degree of democratic progress.

A common feature of these contrasting studies is their limited explicit exploration of pathways of impact, that is, the causal mechanisms linking transitional justice to democracy. Quantitative studies have highlighted where correlations exist (or not) but they tell us little about the means through which transitional justice exerts its effects (whether direct or indirect, and intentional or unintentional). This is illustrated by Olsen, Payne, and Reiter's study which finds that truth commissions are associated with lower levels of subsequent human rights protections. ${ }^{8}$ While this is an important finding, their study tells us little about why truth commissions produce such outcomes. Qualitative studies, in turn, largely take for granted normative aspirations about transitional justice effects and adopt these as measurements for success. For instance, evaluations of truth commission success are often based on whether they satisfactorily fulfil their truth telling mandate, based on the assumption that truth-telling supports democracy building. Yet truth telling can impact democracy positively or negatively: it 
may help strengthen democratic values and diffuse conflicts about the past, but it can equally entrench political polarisation and senses of victimisation. Expanding our understanding of transitional justice impact thus requires a critical engagement with the field's normative assumptions about how transitional justice impacts democracy.

\section{Means of Transitional Justice Impact}

This article focuses on exploring transitional justice's state level or institutional impact, referred to here as 'democratic institution-building'. The aim is to investigate to what extent transitional justice contributes not only to the development of democratic institutions and principles, but also to the performance of these institutions. In order to avoid using unrealistic measurements for transitional justice's impact, it is important to focus on those components of democratic institution-building on which transitional justice can reasonably be expected to have an impact. Therefore, three dimensions were looked at in particular: the rule of law (defined minimally as the presence of an independent and effective judiciary), the security forces (whose democratic character resides in their subordination to civilian control, their non-interference in politics, and their respect for human rights), and participation (defined as citizen's equal access to the political process, independently of ethnicity, religion, gender, regional or political belonging). This choice is empirically grounded - that is, it is at these levels that transitional justice can reasonably be expected to have an impact democracy - but also theoretically based - that is, they are widely recognised in the democracy literature as constitutive elements of democracy. ${ }^{9}$

The focus of the article is on exploring how transitional justice impacts democratic institution-building. So far, studies have insufficiently engaged with theories of change or the causal mechanisms underpinning our assumptions about transitional

justice impact. ${ }^{10}$ Causal mechanisms allow us to peer inside the relationship between 
variables by defining the pathways or processes through which an effect is produced. ${ }^{11}$ In addition to allowing us to look 'inside the black box', they also enable us to integrate in the analysis the possibility that variable $\mathrm{X}$ has different means through which it impacts variable Y. Also, while causal mechanisms are meant to have a general scope and be portable across different social and political contexts, they are also context sensitive. ${ }^{12}$ They therefore make it possible to consider how contextual factors can influence the outcome $\mathrm{X}$ has on $\mathrm{Y}$, a consideration which is particularly important when trying to modulate policy interventions. Overall, causal mechanisms thus allow us to represent the complexities of the social word and the multi-dimensional nature of interactions between variables.

So far, systematic theorisation on the processes linking transitional justice and democratic institution-building is scarce. Nevertheless, common assumptions exist within the literature about how transitional justice exerts impact. Drawing from these, I suggest three possible mechanisms through which transitional justice impacts democracy: (de)legitimation, reform and empowerment. The empirical section will explore to what extent these mechanisms are observed in the Ugandan case, and whether they produce the outcome postulated in the literature. It is important to stress that the causal mechanisms proposed here are not exhaustive but merely exploratory and focused only on explaining transitional justice's state-level or institutional impact. Additional mechanisms such as cognitive reframing and identity reshaping may, for instance, be important in explaining transitional justice's effect on societal or individual-level dimensions such as democratic culture or reconciliation.

\section{(De)legitimation}

A core attribute of transitional justice is that it seeks to shed light on the past by assigning responsibilities for human rights abuses. It therefore has the potential to 
strongly impact views about who does and does not constitute a legitimate political actor in the post-transition era. Through this, transitional justice can impact the distribution of domestic power relations and social capital on which different actors can draw to pursue certain policies or goals, which historical sociologists propose are important factors conditioning democratic outcome.

The causal assumption is that if transitional justice is implemented it may help weaken the influence and power of anti-democratic forces, ${ }^{13}$ which in turn allows for the dismantling of "authoritarian legacies" which would otherwise hamper democratic developments in the rule of law, security forces, and participation. There are various means through which transitional justice is expected to weaken anti-democratic forces. First, it can produce the direct removal of individuals, for instance, when they are sentenced by a court or removed from positions in state institutions following a vetting process. Past abusers are effectively barred from exerting political power, making it more difficult for them to weigh on the political process and block democratic change. Second, in the absence of a direct removal of individuals, transitional justice can also result in 'naming and shaming'. In such instances, the political influence of antidemocratic forces will be eroded through a loss of public support, disavowal by moderate political actors (including in parties linked to the old regime) and/or key international interveners. ${ }^{14}$ Thirdly, through transitional justice, narratives about the past can be produced, reproduced, and contested (or, in the negative, controlled) which can serve to challenge legitimising discourses used by actors or institutions linked to past abuses.

In turn, it is claimed that transitional justice can serve to strengthen nascent democratic forces. ${ }^{15}$ It offers a symbolic means through which the new regime distances itself from formerly abusive actors and affirms its attachment to human rights and 
democratic principles. It can provide the new regime with much-needed international and domestic legitimacy, giving it the necessary political and social capital to dismantle authoritarian enclaves. By highlighting past exclusions and discriminations, and forcing the state to acknowledge these, transitional justice can furthermore re-legitimise and promote the integration of previously excluded groups, thereby broadening the scope for participation.

\section{Reform}

Another way in which transitional justice is expected to impact democracy is by promoting legislative, constitutional, or institutional reforms, which aim to improve the democratic and human performance of institutions. ${ }^{16}$ Transitional justice may trigger reforms such as the dismantlement of previously abusive state institutions, the redefinition of institutional prerogatives and powers, the creation of oversight and human rights monitoring bodies, the adoption of policy measures aimed at addressing structural inequalities, legislative or constitutional revisions strengthening human rights protections, or the introduction of measures to enforce judicial independence and the subordination of the security forces. In this way, transitional justice is thus expected to contribute to the redirection, recalibration and renegotiation of institutions in a way that supports democracy.

The means through which transitional justice may promote reforms is by contributing to the identification of the causes of human rights abuses and the institutional failures which made such abuses possible. This can lead to the formulation of concrete reform recommendations, stimulate public pressures for such reforms, and induce the state to acknowledge and address these institutional failures. Alternatively, transitional justice can promote reforms more indirectly by supporting capacity building of state 
institutions through the provision of human rights or professional training, the distribution of material or financial resources, or providing opportunities for personnel secondment and exchanges. Finally, transitional justice, it is argued, can stimulate reforms by putting forward or demonstrating the validity of new norms, values, and practices - such as respect for international human rights norms, standards of criminal procedure, due process, impartiality, and inclusiveness. ${ }^{17}$

\section{Empowerment}

A more diffuse claim about how transitional justice is linked to democratic institution building is that it can contribute to ending exclusions and marginalisations which would otherwise weaken democratic practices and developments. It can empower individuals to demand state action and serve as a tool for social integration. ${ }^{18}$ In particular, transitional justice is expected to contribute to the empowerment of disadvantaged groups. Depending on the context, these may include ethnic, regional, linguistic or political groups, women, youths, or religious minorities. Transitional justice is thus expected to reshape power relations not only within the state but also between the state and its citizens as it creates a space for previously disempowered actors and citizens more broadly to increase their influence over government.

The means through which transitional justice can do this is by creating spaces where citizen mobilisation can occur, about not only justice demands but also broader human rights, exclusion, and democracy concerns. Transitional justice thus offers a platform and a voice to previously marginalised individuals or communities. Another means through which transitional justice is expected to act is by contributing to the identification and acknowledgment of past exclusions. Transitional justice, it is argued, is well placed to highlight problems of discrimination and disenfranchisement, and 
thereby encourage state responsiveness to these problems. ${ }^{19}$ Transitional justice mechanisms such as courts or truth commissions can directly contest state discriminatory practices or promote marginalised individuals or groups' greater access to resources and services. In this sense, courts and truth commissions can function as tools of legal empowerment. In some instances, transitional justice mechanisms can even directly provide redress to disenfranchised individuals. ${ }^{20}$

\section{Uganda's Incomplete Transition to Democracy}

Uganda presents a mixed record in terms of democratic development. While from independence in 1962 to the 1986 capture of power by the National Resistance Movement (NRM) of current President Yoweri Museveni the country was marked by political instability, mass human rights abuses and authoritarianism, the country has since evolved into a hybrid regime. Such regimes are characterised by the rhetorical adoption of liberal democratic discourses and the implementation of some liberal institutions - such as the organisation of elections - while at the same time keeping in place authoritarian practices and informalised and personalised systems of governance. The country now enjoys a certain degree of stability and multipartism was introduced in 2005, but there remain significant restrictions to civil-political and socio-economic rights while corruption, patrimonialism, divisionism, and militarism persist. $^{21}$ The democratisation process has further been complicated by the persistence of armed rebellions after 1986 in western and northern Uganda, of which the Lord's Resistance Army (LRA) is the most well known.

Concerning the three democracy components of interest to this study - rule of law, the security forces, and participation - unequal progress has been achieved, with the security forces remaining the most problematic. The security forces have played a central role in politics in post-independence Uganda. Both Presidents Milton Obote and 
Idi Amin mobilised the army as their support base and to enforce political control. As a result, the security forces became a major source of political instability and an oppressive social force responsible for mass human rights abuses, both within the security forces, as purges and summary executions were a frequent occurrence, and against civilians. ${ }^{22}$ Museveni worked to reduce the security forces' predatory behaviour and ethnic and regional factionalism, but he has continued to rely on them to enforce his political power. The army, the Uganda People's Defence Forces (UPDF), has been allowed to play a disproportionate role in politics, as illustrated by its 10 guaranteed seats in parliament and the 2013 appointment of an army general as internal affairs minister, while Museveni routinely intervenes in military appointments. Effective parliamentary oversight of the security forces is also limited, particularly when it comes to decision-making on the UPDF's foreign interventions and the military budget. Military force has proven a useful means to accumulate power and gain political capital, while the NRM's historical origins as an armed movement resulted in high value being attached to military ethos and a close intertwining of political and military leaders.

There have been greater improvements in rule of law and participation compared to the security forces, but important lacunae persist. Historically, one of the central challenges to democracy building in Uganda has been the weight of regional and ethnic identities in politics. Practices of ethnic/regional favouritism were widespread under Obote and Amin, fuelling cycles of violence and a zero-sum competition for access to power and resources. ${ }^{23}$ Following its accession to power, the NRM sought to end sectarian exclusions based on ethno-regional belonging by creating a broad-based government integrating northerners and political opponents. But the NRM rapidly veered towards a system of one-party rule while Museveni continued to engage in clientelist practices based on ethnic and regional belonging. Divisions may be less overt 
today but under the NRM political, economic, and military power has been biased in favour of ethnic groups from western and central Uganda. ${ }^{24}$ Participation furthermore suffers from restrictions placed on association rights, a trend which has deteriorated over recent years. While restrictions primarily target political opposition movements, they are also frequently imposed on civil society organisations which mobilise around sensitive issues such as corruption, human rights and national resource management. ${ }^{25}$

In terms of rule of law, despite the independence of the judiciary being enshrined in the Ugandan constitution, political interference is common. Executive interference in judicial appointments at the senior level is particularly problematic, as the president seeks to pre-empt too much judicial independence in politically sensitive cases. While courts have shown a degree of independence in their rulings - most notably with regard to electoral disputes, trials of opposition members, and contentious legislation such as the 2000 Referendum (Political Systems) Act and the 2014 AntiHomosexuality Act - interference in the judicial process and a defiance of judicial rulings by the executive pose a problem. ${ }^{26}$ In addition, inadequate funding and resources negatively impacts judicial effectiveness as it results in a judicial underrepresentation in certain parts of the country, a susceptibility to corruption and backlog in court cases.

\section{A Cautionary Tale: Transitional Justice in a Hybrid Regime}

In the context of this incomplete transition to democracy a multifaceted approach to transitional justice was pursued. This section looks at three measures in particular: trials, commissions of inquiry, and amnesties. Upon seizing power in 1986, the NRM set up a Commission of Inquiry into Violations of Human Rights (CIVHR) to investigate human rights abuses committed by state forces since the country's independence. While it produced a detailed report on state abuses, a lack of resources and political support meant it took eight years to complete its report and was little 
publicised. In response to rebellion outbreaks following the NRM take-over, the government also pursued an amnesty policy which culminated in the adoption of an Amnesty Act in 2000. It offered a blanket and unconditional amnesty to all individuals who had engaged in anti-government insurgencies since 1986, and was accompanied by a demobilisation and reintegration process monitored by the Amnesty Commission. So far, an estimated 26,000 individuals have gone through the amnesty process. In parallel, the government referred the conflict in the north to the International Criminal Court in 2003 and created a Special War Crimes Division at the Uganda High Court in 2003 (which has since been renamed the International Crimes Division, ICD). This resulted in a number of indictments, but trials have been slow to proceed due to difficulties in gaining custody of accused and the application of the amnesty law. ${ }^{27}$

\section{(De)Legitimation}

By highlighting responsibilities for past human rights abuses, transitional justice is expected to contribute to weakening those actors and institutions responsible for such abuses and thereby reduce their ability to hamper democratic transformations. In Uganda, the CIVHR did expose in great detail the responsibility of the security forces under Obote and Amin for human rights abuses. The International Criminal Court (ICC) in turn contributed to drawing increased attention to abuses committed by the LRA and thereby, according to some, forcing external actors to end their support for the group or neglect for the war suffering. ${ }^{28}$ However, there are limited indications that this contributed to containing spoiler actors or otherwise supported democratic institutionbuilding.

A first observation is that it is not straightforward that such attempts at delegitimation contributed to constraining potential spoilers, as it had a minimal impact on the behaviour of actors and did not result in their removal or weakening. Actors linked 
to the past regime went into rebellion immediately after the NRM took power while the ICC indictments did not prevent the LRA from abandoning the Juba peace process. These actors seemed impervious to their de-legitimation by transitional justice processes and it did not weaken their ability or willingness for rebellion and continued commission of human rights abuses. A possible explanation is that there was little follow-up to the CIVHR and that the domestic power balance had changed so drastically by the time its report was published that de-legitimation of the past regime became inconsequential. Similarly, ICC indictments were not followed by the execution of any of the arrest warrants. While it did result in stepped up cross-border military operations against the group, in the short term, this only provoked an intensification of human rights abuses by the LRA. The de-legitimation produced through transitional justice thus amounted merely to a symbolic act with no political consequences attached to it, and is therefore unlikely to have had much bearing on calculations made by actors about whether or not to act as spoilers.

In fact, what has been more effective at reducing the influence of potential spoilers is the process of integration, co-optation and amnesties pursued by the government in response to armed rebellions. The Ugandan government has tended to favour a policy of pacification through integration. Over the years, it has accompanied offers of amnesty with opportunities for rebel actors to integrate in the military (and to some extent also other state institutions). These integration processes have been largely informal though mostly successful in promoting defections from rebel groups and assimilation into the new regime.

This may point to an important difference between countries transitioning from armed conflict and those undergoing a political transition. Most claims about transitional justice's de-legitimation effect have been drawn from post-authoritarian 
transitions. The latter face the challenge of managing past regime collaborators and sympathisers who still operate within the system - whether the security forces, judiciary or state administration - and can therefore destabilise the system from within. Countries experiencing armed conflicts, in contrast, face spoilers who act from outside the state system. Consequently, processes of de-legitimation may not be as effective or appropriate in both contexts. Especially since diverse responsibilities for human rights abuses and political instrumentalisation are more likely to distort transitional justice's de-legitimation effects in (post-) conflict environments.

Theories about transitional justice's effect through de-legitimation assume that there is a relatively clear delineation between perpetrators and victims and between former and past regime. In the case of Uganda, such delineations are murky as a wide variety of actors are responsible for human rights abuses. In such contexts who 'needs' to be de-legitimised or which authoritarian enclave should be dismantled is a complex and multi-dimensional problem. Most often both state and non-state actors are responsible for human rights violations and can act as spoilers to democratisation efforts. The challenge for transitional justice therefore lies in properly taking into account the role of these various actors and in avoiding being mobilised to serve the political interest of one actor, to prevent producing an undesirable 'reverse legitimation'. It is precisely at this level that transitional justice mechanisms in Uganda have failed.

In effect, transitional justice processes have failed to de-legitimise an important actor responsible for human rights abuses: the UPDF. Although the UPDF was newly created after 1986, and therefore does not represent an institution linked to past abusive regimes, the army constitutes a form of authoritarian enclave within the Ugandan state which weighs on democratic developments. Yet the actions of the UPDF have not 
formed part of transitional justice debates in the country. Already at the time of transition, the CIVHR was specifically barred from looking into the actions of the NRM and crimes committed after 1986. Both the ICC and the ICD have so far also refrained from investigating human rights abuses committed by the army. ${ }^{29}$ The Amnesty Act, in turn, focuses exclusively on crimes committed by non-state actors. While this means there is no legal bar to the prosecution of state forces, it has, in practice further contributed to removing the question of army abuses from transitional justice debates.

The Ugandan government has deliberately sought to exclude the security forces from the scope of transitional justice processes. It promotes the view of transitional justice as a 'special' form of justice dealing with the crimes committed by non-state actors. Its referral to the ICC was clearly aimed at the LRA, while the ICD was similarly seen as a domestic instrument exclusively meant for the prosecution of rebel and terrorist groups. In contrast, the government argues that crimes committed by the security forces fall under the purview of domestic military courts, thereby rendering 'exceptional' justice measures to deal with such crimes unnecessary. In practice, however, there are few known cases of soldiers tried for war crimes before military courts, with most trials limited to smaller criminal offenses such as theft or cases of indiscipline and illegal detention of weapons. ${ }^{30}$ The military authorities and government have also been deliberately opaque by not making available a list of court martial cases or publishing rulings. ${ }^{31}$

Excluding state human rights abuses from the scope of transitional justice processes has allowed the government to downplay abuses committed by the security forces. Abuses are presented as merely resulting from individual excesses rather than reflecting an institutional problem. State officials have in particular used the ICC's decision to only focus on LRA crimes to 'clear' the UPDF of any wrongdoing, in a bid 
to sustain its domestic and international standing. ${ }^{32}$ This not only had the effect of curtailing accountability for the security forces, but also, more broadly debates about the role of the military in Ugandan politics and society. By sidestepping the problem of army abuses transitional justice mechanisms have been unable to make a positive contribution to a democratic transformation of the security forces. Instead, they have (unwittingly) contributed to legitimising an undemocratic and abusive army and its continued role in Ugandan politics.

Transitional justice has furthermore been instrumentalised to bolster the government's own legitimacy. Transitional justice has proven a useful instrument for self-legitimation and to tip the domestic balance of power in the government's favour. The CIVHR, for instance, served to scapegoat past regimes and bolster the NRM's international credibility and popular legitimacy by seeming to act on its promise of ending misuse of power and human rights abuses. ${ }^{33}$ The ICC in turn has been mobilised to win international backing for the government, at a time when its military operations at home and abroad faced increasing criticism. ${ }^{34}$ The success of this strategy was most clearly illustrated by the announcement by the USA in 2011 that it would send 100 Special Operations Forces to support UPDF operations against the LRA. Referring to the ICC also enabled Kampala to criminalise and thereby de-politicise the northern conflict. As Nouwen and Werner argue, the ICC process allowed the government to promote the view of the LRA as criminals and 'enemies of humankind' while rebranding itself as a champion of the international community. ${ }^{35}$ By focusing solely on the northern conflict, the ICC investigations furthermore enabled a framing of the human rights issue as merely constituting 'an LRA problem'.

While it is undeniable that the LRA has committed atrocious crimes, solely framing the problems in terms of criminality overshadows broader conflict dynamics 
throughout the country - not just in Acholi - and wider governance problems which underpin the armed conflicts and human rights problems. Similarly, planned trials before the ICD of Allied Democratic Forces rebels, ${ }^{36}$ a rebel group from the western Rwenzori region currently based in neighbouring Democratic Republic of the Congo, would serve to support the government's long-standing efforts to brand the group as terrorist and fundamentalist while avoiding any discussion of the political and socioeconomic factors underpinning long-standing discontent in that region. Thus criminal trials are used by the government as an instrument to defeat its (political) opponents and avoid addressing drivers of regime discontent. At the same time, it offers a means to divert international focus away from the government's own misconduct and poor governance. This fits into a broader 'image management' strategy pursued by the Ugandan government to win donor support and contain international criticism of the regime. ${ }^{37}$ Criminal trials have thus not provided an impetus for democratic change but rather enabled the government to maintain the status quo and counteract donor pressures for democratic change.

\section{Reform}

A second way in which transitional justice is expected to contribute to democratic institution-building is the promotion of institutional and legislative reforms. By highlighting institutional failures that were responsible for past human rights abuses and demonstrating respect for human rights and democratic principles, transitional justice mechanisms can create an impetus for such reforms and produce changes in institutional behaviour. In Uganda, transitional justice has to some extent spurred on reform debates and catalysed the introduction of constitutional and legislative changes. However, the scope of these reforms and their translation into a transformation of institutional practices is limited. 
Both the CIVHR and the ICC have contributed to stimulating reforms. Although few of its recommendations were taken on by the government, the CIVHR was able to weigh in on reform processes through its participation in consultations on the drafting of a new constitution. It submitted a proposal to the Constitutional Commission in which it called for the integration of a comprehensive bill of rights in the Constitution and the creation of a national human rights commission. ${ }^{38}$ These suggestions were integrated in the new constitution, resulting in the creation of the Ugandan Human Rights Commission (UHRC). The ICC has similarly, and maybe even to a larger extent, spurred on reforms. Although some of these resulted from opposition to the Court, that is, they were adopted in a bid to pre-empt ICC trials, they nevertheless denote important changes. Thus, the adoption of the ICC Act in 2010 introduced modifications in domestic criminal law, in particular the criminalisation of war crimes, crimes against humanity and genocide. More broadly, the ICC's intervention exposed government and judicial actors to concepts of international criminal justice and thereby stimulated further legislative debates beyond the adoption of the ICC Act. ${ }^{39}$ For instance, it has focused greater attention on questions of due process, victim participation and reparations in domestic trials, while also served as a catalyst for the drafting of legislation on witness protection and the introduction of amendments to the penal code regarding gender-based violence. ${ }^{40}$ Accountability debates triggered by the ICC have further contributed to increasing the profile and political support for the Justice Law and Order Sector (JLOS), a state body created in 2001 coordinating the activities of government agencies working in the justice and law and order sector, thereby enhancing institutional capacity to promote rule of law.

While transitional justice produced a reform effect, the scope of this appears restricted. Firstly, reforms only concerned rule of law, not the security forces or 
participation. The CIVHR made recommendations in both these areas - such as the instauration of civil oversight over and de-ethnicisation of the security forces, the instauration of political rights, and redressing of past exclusionism and regional development imbalances - but these did not result in the adoption of concrete reform measures. $^{41}$ Trials in turn have not dealt with the security forces, as already discussed, or investigated crimes that highlight problems of exclusion and marginalisation. Where reform measures were adopted in these areas they have been largely detached from transitional justice. For instance, accountability debates weighed little on government decision-making about reconstruction plans for the north or the 2013 National Land Policy. Similarly, security sector reforms and defence reviews have been divorced from accountability debates. The latter were essentially focused on promoting army integration, modernisation and army restructuring and did not integrate concerns about ending impunity. While the CIVHR was in operation, the government pursued a parallel security sector policy premised on the idea of 'stabilisation through integration', which relied on the accommodation of those responsible for human rights abuses rather than instilling practices of accountability. Even the more recent Uganda Defence Review carried out in 2002-2004 mostly refers to accountability in terms of financial management rather than in terms of oversight of the army's human rights practices.

It is worth exploring, however, whether transitional justice exerted a reform effect in an indirect fashion, through the creation of a more human rights-sensitive environment. Over time, transitional justice processes produced a normative shift by placing questions of accountability and human rights more centre stage in societal and political debates within Uganda. As a result, there is now greater scrutiny of human rights practices by civil society and donors, leading to heightened government sensitivity to this issue. This in turn, can result in greater responsiveness on its part and 
willingness to implement reforms. Evidence that this may be occurring can be found in the recent creation of a Human Rights Directorate within the army, the adoption of new rules on cordon and search operations, and the appointment of civil-military officers following widespread criticisms of military operations in the Karamoja region. ${ }^{42}$ However, this increased sensitivity to human rights criticisms also results from the country's donor dependency which creates reputational concerns. As the regime is keen to win international legitimacy and promote itself as a capable regional military power, it seeks to act on human rights concerns where this can build its international image - or to cover them up when it threatens the regime and national army's reputation. ${ }^{43}$ Thus, even where transitional justice contributes to creating a more human rights-sensitive environment, this may not always be sufficient to promote a genuinely reform-minded government.

The scope of transitional justice's reform effect is also restricted to the extent that it has mostly been limited to formal changes rather than modifications in institutional practice. Thus while the UHRC has contributed to placing the spotlight on human rights concerns and introducing a certain degree of oversight over state human rights practices, it has been timid in addressing abuses committed by the security forces during the armed conflicts. Its ability to be a genuinely independent body has shown to be limited, in particular when it comes to the actions of the military. Although it is too early to determine with certainty the effect of the more recently adopted reforms, preliminary findings suggest that beyond the integration of specific rights protections in domestic law, courts have had little impact on changing state practices on rule of law. There are three reasons for this.

First, the political will to promote rule of law is mostly absent. The government allows human rights legislative changes where this can boost its credentials and does 
not pose an immediate political threat. But its adherence to rule of law principles remains sketchy and executive interference in the judiciary persists. A recent illustration of this was the contentious re-appointment of Benjamin Odoki as Chief Justice in 2013, in violation of the Constitution. The government also does not demonstrate greater willingness to pursue broader policies aimed at improving judicial effectiveness, such as tackling corruption in the judiciary or improving citizen's access to justice. ${ }^{44}$ Transitional justice's reform effect, though not negligible, has failed to produce substantial behavioural change as the government's attitude towards the judiciary remains dominated by political considerations.

A second factor is transitional justice's weak contribution to bolstering judicial capacity in a sustainable fashion. Transitional justice processes resulted in punctual investments in capacity-building efforts, either by transitional justice mechanisms themselves (more specifically the ICC) or by third actors stimulated by the increase in accountability debates (NGOs and donors). But it is unclear that these have made substantive contributions. Training efforts have largely focused on international criminal and human rights law and ICD judges and registry staff, to the neglect of capacity-building efforts for other parts of the Ugandan judiciary. Even if one adopts the view that transitional justice should only focus on its domain of speciality - criminal justice - there have been significant challenges. Training provided to the ICD has not focused enough on strengthening prosecutorial, defence and administrative capacities while the high rotation of personnel within the ICD means that much of the training 'got lost' ${ }^{45}$ While this could, in principle, promote the spread of knowledge throughout the judiciary as people move to new posts, in practice, it appears, many feel that outside of the ICD, they have little use for the specific knowledge provided through these trainings and that the latter were therefore wasteful. ${ }^{46}$ Trainings provided by the ICC are even 
more problematic as they focused on sensitising people about the Court and inciting greater cooperation from domestic officials, rather than investing in strengthening domestic judicial capacity or providing assistance to encourage domestic prosecutions. ${ }^{47}$

Lastly, transitional justice's reform effect is also curtailed by the shortcomings of transitional justice mechanisms themselves. This is particularly the case of trials, which have not always acted in respect of rule of law principles. The ICC, by focusing only on crimes committed by the LRA, has entrenched inequality before the law. ${ }^{48}$ In turn, the Kwoyelo trial before the ICD has highlighted a number of problems. The fact that only Kwoyelo was indicted and refused amnesty, while other LRA fighters including such senior commanders as Caesar Achellam were not, signals unfairness in the judicial process. It also suggests a political character to the trail processes before the ICD. ${ }^{49}$ The 2011 Constitutional Court ruling in the Kwoyelo case, which found that the ICD's refusal to apply amnesty to Kwoyelo amounted to unequal treatment before the law, counteracts this in so far as it denotes respect for due process and judicial independence. However, the public prosecutor and JLOS's rejection of this ruling indicates a lack of respect for the judicial process. ${ }^{50}$ The difficulties the ICC and ICD face in obtaining custody of accused or opening investigations - as a result of a lack of political will, weak judicial capacity, and the blanket amnesty - further entrenches perceptions that rule of law is not a priority. If trials are themselves not seen as agents of rule of law, they are unlikely to substantially contribute to improving broader institutional performance on this front. The above observations strongly suggest that even though transitional justice can impact democracy by promoting reforms, its effect is contingent on their embedment in broader reform processes.

\section{Empowerment}

A final claim about transitional justice is that it contributes to empowering individuals 
by creating a new space and language for mobilisation, thereby increasing the scope for participation. One way in which it might do so is by shining the light on problems of marginalisation and discrimination, promoting their acknowledgment by the state, and giving a voice to disenfranchised groups. While marginalisation poses a central challenge in Uganda, evidence of transitional justice's empowerment effect is ambivalent. The main reason for this is that transitional justice mechanisms have mostly not addressed this issue.

Neither truth commissions nor trial processes have really addressed problems of marginalisation and discrimination. The CIVHR contained one chapter dealing with 'discriminatory treatment' but its scope was limited. ${ }^{51}$ But it failed to place the issue within a broader debate about ethno-regional divisions and marginalisation as a structural governance problem. Marginalisation was treated as essentially a political problem (in that it affects the ability of certain elites to participate in state institutions) rather than as a socio-political problem (in that it involves structural obstacles to participation of broader societal groups). While truth commissions have the ability to highlight problems of discrimination, inequality and social injustice - as illustrated by the Guatemalan and Peruvian truth commissions - this was not the case of the CIVHR which focused primarily on violations of physical integrity rights.

Courts' contribution to the empowerment of marginalised groups in Uganda has similarly been limited. Because no trials have taken place - apart from the aborted trial of LRA commander Thomas Kwoyelo before the ICD - courts have not had the opportunity to exert such an effect. If trials did take place, its empowerment effect would likely depend on the nature of the crimes prosecuted and the extent of victim participation in the proceedings. However, one limitation that can already be observed is courts' restrictive focus on the LRA. This hampers their empowerment effect because 
it contributes to perpetuating views of the Acholi as 'different' and 'problematic' and fails to challenge non-inclusive conceptions of national identity which persist in the country. ${ }^{52}$ Moreover, it entails the risk that other regions and communities affected by conflict will see criminal courts as a mechanism that does not concern itself with their sufferings. It would also fail to publicly highlight the abuses and marginalisation suffered by these other groups. In this way, courts can unwittingly contribute to perpetuating the disenfranchisement of certain groups.

In contrast, although memorials have so far not taken centre stage in transitional justice debates in Uganda, there are suggestions that they could support empowerment. Local communities are increasingly turning towards such practices, which serve as useful spaces to voice their demands to the government. For local communities, memorials are first and foremost about ensuring that knowledge about what happened is transmitted to future generations. It is about building a heritage of the conflict and building a space for collective history. ${ }^{53}$ But it has been suggested that communities also see memorials as a way to emphasise broader aspects of the conflict, to highlight their grievances and demand government acknowledgment. ${ }^{54}$ This is generally with the aim of obtaining reparations from the government but may also serve to highlight issues of marginalisation and disenfranchisement, which communities do not dare to express through other political means out of fear for retribution. ${ }^{55}$ Victims are reportedly also using memorial spaces to foster social reconstruction and mobilise around social justice demands such as access to land and gender issues. ${ }^{56}$ While further research is needed to confirm these preliminary findings, it suggests an interesting way in which transitional justice could produce an empowerment effect.

The Ugandan amnesty process also suggests ways in which such mechanisms can support empowerment of disenfranchised individuals and groups. While amnesties 
were adopted as a means to encourage the disarmament of rebel groups, they also served as a means to acknowledge the particular victimisation of northern populations by both the government and the LRA, and the fact that many LRA fighters and dependents were abductees. It followed from this view that the amnesty had to be linked to a broader process of reintegration and social reconstruction. This was partially done by integrating the amnesty and the disarmament, demobilisation and reintegration process, and linking these to the Peace, Recovery and Development Plan (PRDP), a government initiative aimed at addressing the marginalisation and reconstruction of the north launched in 1992 (under the initial name Northern Uganda Reconstruction Project). Placing amnesties within a broader framework of reintegration policies can potentially support the empowerment of disenfranchised individuals.

In the Ugandan case, however, there have been important shortcomings which have limited amnesties' impact on this front. Primarily this is because the amnesty process has focused solely on the reintegration of ex-combatants (and their dependants) and not been accompanied by support measures for local communities. This has created growing resentment amongst local populations who feel that the amnesty has ultimately served a political rather than a social purpose. Some continue to feel neglected by state authorities and have opposed the reintegration of ex-LRA members in their local communities. ${ }^{57}$ This is exacerbated by the fact that the government has systematically sought to bypass the issue of reparations on the grounds that the PRDP was set up to provide support to conflict-affected communities, though in practice it has tended to focus more on reconstruction and infrastructure projects rather than on redressing socioeconomic imbalances and promoting livelihood projects. ${ }^{58}$ Furthermore, complex local dynamics and the sometimes fluid line between victims and perpetrators have meant that blanket amnesties have been seen by local communities as insufficient to 
support reintegration, and led them to turn to community-based practices involving aspects of confession and atonement to fill this void. ${ }^{59}$ Lastly, a lack of resources and political support has made it difficult for the Amnesty Commission to provide more targeted support to particularly disenfranchised individuals such as women and children. Thus while there are indications that transitional justice can contribute to democratic institution-building through empowerment, in the Ugandan case this promise was not fulfilled due to mechanisms' institutional limitations and lack of focus on this potential role.

\section{Conclusion}

Whether or not transitional justice supports democratic institution-building remains a contentious point of debate in transitional justice scholarship, and evidence to this end is contradictory. This paper sought to contribute to this debate by investigating some of the normative assumptions about how transitional justice links to democratic institutionbuilding. Looking at the case of Uganda, the findings suggest that transitional justice's impact on democratic institution-building through three proposed pathways - (de-) legitimation, reform, and participation - is more circumscribed than has so far been assumed. While transitional justice's (de-)legitimation effect contributed negatively to democratic institution-building, it did impact the latter through the reform effect though only with regards to the rule of law. It also remains to be seen to what extent this will subsist over time and trickle-down to produce effective changes in practice. At this stage, evidence of transitional justice's empowerment effect is also more suggestive than actual. Overall, transitional justice mechanisms in Uganda have contributed little to democratic institution-building through the three pathways of impact.

There are two important implications that can be drawn from this research: one theoretical and one practical. At the theoretical level, the findings highlight that 
prevailing ideas about how transitional justice impacts democratic institution-building (whether negatively or positively) are overall poorly conceptualised. There is a need for more theorising about the causal mechanisms linking both. Indeed the negative findings drawn here from the Ugandan case do not necessarily mean that transitional justice in general has no impact on democratic institution-building. Rather, it could simply signify that other, as yet unidentified, causal mechanisms are at play. Moreover, the fact that a particular pathway of impact, such as de-legitimation, can have both a positive and negative impact demonstrates that more attention needs to be paid to specifying the component parts of proposed causal mechanisms. There are clearly multiple ways in which processes of de-legitimation or empowerment can operate. These processes may moreover operate differently in function of the context in which they take place. Understanding the different steps and conditions under which transitional justice operates these effects is essential to improving our ability to assess its impact, and identify when transitional justice will and will not make a positive contribution.

At a more practical level, the Ugandan experience highlights the difficulties transitional justice faces when implemented in a conflict environment and hybrid regime. It strongly suggests that expectations about transitional justice's ability to support democratic-institution building in such contexts need to be lowered. This is not to say that transitional justice should never be pursued in such context, but that due consideration needs to be given to the particular challenges it poses. In conflict environments, the multiplicity of actors responsible for abuses, the lack of clear delineation between 'old' and 'new' regime, and state actors' prioritisation of other policy goals such as stabilisation means that transitional justice mechanisms are at risk of (unwittingly) legitimising and reinforcing one or the other party to the conflict. In the context of hybrid regimes, where a logic of regime survival and habit of using 
'democratic trappings' as a means of regime legitimation tend to dominate, transitional justice is at acute risk of political instrumentalisation. While transitional justice may nevertheless contribute to creating little pockets of change in such countries - as exemplified in Uganda by the legislative reforms on human rights triggered by ICC debates and local communities' mobilisation of memorials as spaces to express sociopolitical demands - it remains an open question whether this is sufficient to produce sustainable democratic change. The Ugandan case thus seems to support claims that transitional justice is dependent on the achievement of a minimum of democratic progress. But even more importantly, it suggests that viewing the relationship between transitional justice and democratic institution-building as interdependent (depending on time and context, one or the other may reinforce the other) rather than unidirectional (transitional justice causes or hampers democracy) may be a more fruitful way for advancing our understanding of transitional justice's impact.

\section{Acknowledgments}

The article forms part of a broader comparative research project on 'The impact of transitional justice measures on democratic institution-building', undertaken jointly at the School of Business and Law, University of East London, and the Netherlands Institute for Human Rights, Utrecht University (www.tjdi.org). The author would like to thank Chandra Lekha Sriram and two anonymous reviewers for their helpful comments on drafts of this article.

\section{Funding}

This article was supported by the Economic and Social Research Council [grant number ES/K006118/1]. 


\section{Notes}

1. Thoms, Ron and Paris, "The Effect of Transitional Justice", 4.

2. The year 1986 is taken as the transition moment because the NRM's arrival into power signalled a change in regime. Although the transition failed to produce full democracy, this does not change the fact that 1986 represents a transitional moment that offered an opportunity for democratic change.

3. Minow, Between Vengeance ; Sikkink and Walling, "The Impact of Human Rights Trials"; Nettelfield, Courting Democracy; Horne, "Assessing the Impact"; Weiffen, "The forgotten factor".

4. Snyder and Vinjamuri, "Trials and Errors"; Wiebelhaus-Brahm, Truth Commissions; Olsen, Payne and Reiter, Transitional Justice; McMahon and Forsythe, “The ICTY's Impact”.

5. Osiel, Mass Atrocity; Bloxham, Genocide.

6. Kim, "Local, National, International Determinants".

7. Skaar, Judicial Independence.

8. Olsen, Payne and Reiter, Transitional Justice, 144-146.

9. Arnould and Sriram, Pathways of Impact, 3-4. The conceptualisation of democracy used here draws from the literature on the quality of democracy and from Morlino, "Authoritarian Legacies".

10. Duggan, "Show me your Impact", 203; Mendeloff, "Truth-Seeking".

11. Gerring, "The Mechanismic Worldview", 163-164; Elster, “A plea for mechanisms", 47-49; Mahoney, "Beyond Correlational Analysis", 580-581.

12. Falleti and Lynch, "Context", 1145.

13. Akhavan, "Beyond Impunity"; Burke-White, "Double Edged Tribunals", 22-26.

14. Wiebelhaus-Brahm, "Promoting Accountability".

15. Barahona de Brito et.al, The Politics of Memory, 313.

16. Hayner, Unspeakable Truths, 190-194; Van Zyl, "Promoting Transitional Justice”, 216.

17. Ndulo and Duthie, "Role of Judicial Reform", 266-267; de Greiff, "A Normative Conception", 28.

18. de Greiff, "Articulating the Links", 55-62.

19. O'Connell, Empowering the Disadvantaged.

20. Muddell, Limitations and Opportunities, 2.

21. Kjaer, "Fundamental Change"; Tripp, Museveni's Uganda.

22. Brett, "Neutralising the Use of Force", 136-138.

23. Kibanja, Kajumba and Johnson, "Ethnocultural Conflict".

24. Lindemann, "Just Another Change of Guard?", 395-405; Minorities at Risk Dataset. 


\section{Human Rights Watch, Curtailing Criticism.}

26. Tripp, Museveni's Uganda, 86-91; International Bar Association, Judicial Independence.

27. One of the ICC indictees, Raska Luwiya, has since been confirmed dead while two others, Vincent Otti and Okot Odhiambo, are suspected to have died in 2007 and 2013 respectively. LRA commander Domnic Ongwen was transferred to the ICC following his capture/surrender in the Central African Republic in January 2015. The case before the ICD against Thomas Kwoyelo stalled after a 2011 ruling that the amnesty was applicable, but is expected to resume after the Supreme Court reversed this decision in April 2015. ADF leader Jamil Mukulu is expected to be tried before the ICD following his capture in Tanzania in April 2015.

28. Akhavan, "The LRA Case", 416; for a divergent view see Refugee Law Project, Ambiguous Impacts, 15-18.

29. For a critical discussion of the ICC's prosecutorial choices see Clark, "Chasing Cases".

30. Interview with Ugandan civil society actor, Kampala, February 2014; Human Rights Watch, Uprooted and Forgotten, 41-45.

31. Interview with foreign official, Kampala, February 2014.

32. Nouwen, The ICC's Intervention, 24.

33. Quinn, "Constraints", 417.

34. Branch, "Uganda's Civil War", 184; Freeland, "Rethinking the State", 309.

35. Nouwen and Werner, "Doing Justice", 947-950.

36. Interview with judicial official, Kampala, February 2014.

37. Fisher, "When it pays to be a Fragile State".

38. Quinn, “Constraints”, 419

39. Wierda, "Comparison of the Legacy".

40. Nouwen, The ICC's Intervention, 10-11; Interviews with Ugandan and international civil society actors, Kampala, February 2014.

41. CIVHR report, 587-605.

42. Interview with foreign official, Kampala, February 2014; Human Rights Watch, "Get the Gun!", 67.

43. Kampala's sensitivity to allegations of army human rights abuses when these might affect the international standing of the regime and UPDF is illustrated by its vociferous reaction to the publication of the UN Mapping Exercise Report in 2010, which detailed human rights abuses committed by the UPDF in neighbouring DRC, and its subsequent threat to close the OHCHR office in the country in retaliation. http://www.ohchr.org/Documents/Countries/ZR/DRC Report Comments Uganda.pdf 
44. Interviews with Ugandan civil society actors and foreign official, Kampala, JanuaryFebruary 2014.

45. International Crimes Division Annual Report 2012; Interview with Ugandan lawyer, Kampala, February 2014.

46. Interviews with Ugandan and international civil society actors and ICC official, Kampala, February 2014.

47. Interviews with Ugandan civil society actor and ICC official, Kampala, February 2014.

48. Nouwen, The ICC's Intervention, 22-24.

49. Interviews with Ugandan lawyer and foreign official, Kampala, February 2014.

50. Interview with Ugandan civil society actor, Kampala, February 2014.

51. CIVHR report, 512-531.

52. Interview Uganda civil society actor, Kampala, February 2014.

53. Blackmore, "Creating a Conflict Heritage".

54. Interview with Ugandan civil society actor, Kampala, January 2014.

55. Interview with international civil society actor, Kampala, February 2014.

56. Interview with Ugandan civil society actor, Kampala, January 2014.

57. Interviews with Ugandan lawyer and with member of the Amnesty commission, Kampala, February 2014; Justice and Reconciliation Project, Who Forgives Whom?, 3-4.

58. Interviews with Ugandan civil society actor and foreign official, Kampala, February 2014.

59. Clark, "Bringing them all back home", 248.

\section{References}

Akhavan, Payam. "Beyond Impunity: Can International Criminal Justice Prevent Future Atrocities?" American Journal of International Law 95, no. 1 (2001): 7-31.

Akhavan, Payam. "The Lord's Resistance Army Case: Uganda's Submission of the First State Referral to the International Criminal Court." American Journal of International Law 99, no. 2 (2005): 403-421.

Arnould, Valerie, and Chandra Lekha Sriram, Pathways of Impact: How Transitional Justice Affects Democratic Institution-Building, TJDI Policy Brief 1, London: University of East London, October 2014.

Barahona de Brito, Alexandra, Carmen Gonzalez-Enriquez, and Paloma Aguilar, eds. The Politics of Memory. Transitional Justice in Democratizing Societies. Oxford: Oxford University Press, 2001. 
Blackmore, Kara. "Creating a Conflict Heritage in Northern Uganda." Reconciliation Barometer Newsletter 11, no. 2 (2013): 10-11.

Bloxham, Donald. Genocide on Trial: War Crimes Trials and the Formation of Holocaust History and Memory. Oxford: Oxford University Press, 2001.

Branch, Adam. "Uganda's Civil War and the Politics of ICC Intervention." Ethics and International Affairs 21, no. 2 (2007): 179-198.

Brett, E.A. "Neutralising the Use of Force in Uganda: The Role of the Military in Politics." Journal of Modern African Studies 33, no. 1 (1995): 129-152.

Burke-White, William W. "Double Edged Tribunals: The Political Effects of International Criminal Tribunals." Guest lecture series of the Office of the Prosecutor, International Criminal Court, 28 July 2006.

Clark, Phil. "Bringing them all back home: The Challenges of DDR and Transitional Justice in Contexts of Displacement in Rwanda and Uganda." Journal of Refugee Studies 27, no. 2 (2014): 234-259.

Clark, Phil. "Chasing Cases: The ICC and the Politics of State Referral in the Democratic Republic of Congo and Uganda." In The International Criminal Court and Complementarity: From Theory to Practice, edited by Carsten Stahn and M.L Zeidy, 1180-1203. Cambridge: Cambridge University Press, 2010.

CIVHR, Report of the Commission of Inquiry into Violations of Human Rights Findings, Conclusions and Recommendations. Kampala: UPPC, October 1994.

de Greiff, Pablo. “A Normative Conception of Transitional Justice." Politorbis 10, no. 3 (2010), 18-30.

de Greiff, Pablo. "Articulating the Links Between Transitional Justice and Development: Justice and Social Integration.” In Transitional Justice and Development. Making Connections, edited by Pablo de Greiff and Roger Duthie, 28-75. New York: ICTJ, 2009.

Duggan, Colleen. "“'Show me your impact": Evaluating Transitional Justice in Contested Spaces." Evaluation and Program Planning 35, no. 1 (2012): 199-205.

Elster, Jon. "A Plea for Mechanisms" in Social Mechanisms: An Analytical Approach to Social Theory, edited by Peter Hedström and Richard Swedberg, 45-73. New York: Cambridge University Press, 1998.

Faletti, Tulia G., and Julia Lynch. "Context and Causal Mechanisms in Political Analysis." Comparative Political Studies 42, no. 9 (2009): 333-339. 
Fisher, Jonathan. "When it pays to be a "Fragile State": Uganda's Use and Abuse of a Dubious Concept." Third World Quarterly 35, no. 2 (2014): 316-332.

Freeland, Valerie. "Rebranding the State: Uganda's Strategic Use of the International Criminal Court." Development and Change 46, no. 2 (2015): 293-319.

Gerring, John. "The Mechanismic Worldview: Thinking Inside the Box." British Journal of Political Science 38, no. 1 (2008): 161-179.

Hayner, Priscilla. Unspeakable Truths: Facing the Challenge of Truth Commissions. New York: Routledge, 2010.

Horne, Cynthia. "Assessing the Impact of Lustration on Trust in Public Institutions and National Government in Central and Eastern Europe." Comparative Political Studies 45, no. 4 (2012): 412-446.

Human Rights Watch. Curtailing Criticism. Intimidation and Obstruction of Civil Society in Uganda. New York, 21 August 2012.

Human Rights Watch. “Get the Gun!” Human Rights Violations by Uganda's National Army in Law Enforcement Operations in Karamoja Region. New York, September 2007.

Human Rights Watch. Uprooted and Forgotten. Impunity and Human Rights Abuses in Northern Uganda. New York, September 2005.

International Bar Association. Judicial Independence Undermined: A Report on Uganda. London, September 2007.

International Crimes Divisions of the Ugandan High Court, ICD Annual Report 2012. Kampala, January 2013.

Justice and Reconciliation Project. Who Forgives Whom? Northern Uganda's Grassroots Views on the Amnesty Act. Gulu, June 2012.

Kibanja, Grace M., Mayanja M. Kajumba, and Laura R Johnson. "Ethnocultural Conflict in Uganda: Politics Based on Ethnic Divisions Inflame Tensions Across the Country." In Handbook of Ethnic Conflict: International Perspectives, edited by Dan Landis and Rosita D. Albert, 403-435. New York: Springer, 2012.

Kim, Hun Joon. "Local, National, and International Determinants of Truth Commission: The South Korean Experience.” Human Rights Quarterly 34, no. 3 (2012): 726-750.

Kjaer, Mette. "Fundamental Change or No Change? The Process of Constitutionalizing Uganda.” Democratization 6, no. 4 (2007): 93-113.

Lindemann, Stefan. "Just Another Change of Guard? Broad-Based Politics and Civil War in Museveni’s Uganda.” African Affairs 110, no. 440 (2011): 387-416. 
Mahoney, James. "Beyond Correlational Analysis: Recent Innovations in Theory and Method." Sociological Forum 16, no. 3 (2001): 575-593.

McMahon, Patrice C., and David P. Forsythe. "The ICTY's Impact on Serbia: Judicial Romanticism meets Network Politics." Human Rights Quarterly 30, no. 2 (2008): 412435.

Mendeloff, David. "Truth-Seeking, Truth-Telling, and Postconflict Peacebuilding: Curb the Enthusiasm?" International Studies Review 6, no. 3 (2004): 355-380.

Minority at Risk, Minorities at Risk Dataset. College park, MD: Center for International Development and Conflict Managment, 2009.

Minow, Martha. Between Vengeance and Forgiveness: Facing History After Genocide and Mass Violence. Boston: Beacon Press, 1998.

Morlino, Leonardo. "Authoritarian Legacies, Politics of the Past and the Quality of Democracy in Southern Europe: Open Conclusions." South European Politics and Society 15, no. 3 (2010): 507-529.

Muddell, Kelly. Limitations and Opportunities of Reparations for Women's Empowerment. New York: ICTJ, September 2009.

Ndulo, Muna B., and Roger Duthie. "The Role of Judicial Reform in Development and Transitional Justice.” In Transitional Justice and Development. Making Connections, eds. Pablo de Greiff and Roger Duthie, 250-281. New York: ICTJ, 2009.

Nettelfield, Lara J. Courting Democracy in Bosnia-Herzegovina. The Hague Tribunals' Impact in a Postwar State. Cambridge: Cambridge University Press, 2010.

Nouwen, Sarah. The ICC's Intervention in Uganda: Which Rule of Law Does it Promote?. Legal Studies Research Paper Series No. 22, Cambridge University: Faculty of Law Legal Studies, 2012.

Nouwen, Sarah M.H., and Wouter G. Werner, "Doing Justice to the Political: The International Criminal Court in Uganda and Sudan.” European Journal of International Law 21, no. 4 (2011): 941-965.

O'Connell, Jamie. Empowering the Disadvantaged After Dictatorship and Conflict: Legal Empowerment, Transitions and Transitional Justice. International Development Law Organization Paper No. 8, Rome: IDLO, 2009.

Olsen, Tricia D., Leigh A. Payne, and Andrew G. Reiter. Transitional Justice in Balance. Comparing Processes, Weighing Efficacy. Washington, DC: Unites States Institute of Peace Press, 2010. 
Oseil, Mark A. Mass Atrocity, Collective Memory and the Law. New Brunswick, NJ: Transaction Publishers, 1997.

Quinn, Joanna R. "Constraints: The Un-Doing of the Ugandan Truth Commission." Human Rights Quarterly 26, no. 2 (2004): 401-427.

Refugee Law Project. Ambiguous Impacts. The Effects of the International Criminal Court Investigations in Northern Uganda. Working Paper No. 22, Kampala: RLP, October 2012.

Sikkink, Kathryn, and Carrie Booth Walling. "The Impact of Human Rights Trials in Latin America." Journal of Peace Research 44, no. 4 (2007): 427-455.

Skaar, Elin. Judicial Independence and Human Rights in Latin America. Violations, Politics, and Prosecutions. Basingstoke: PalgraveMacmillan, 2011.

Snyder, Jack L., and Leslie Vinjamuri. "Trials and Errors: Principle and Pragmatism in Strategies of International Justice.” International Security 28, no. 3 (2003): 5-44.

Thoms, Oskar N.T., James Ron, and Roland Paris. The Effect of Transitional Justice Mechanisms. A Summary of Empirical Research Findings and Implications for Analysts and Practitioners. CIPS Working Paper, University of Ottowa: Centre for International Policy Study, April 2008.

Tripp, Aili Mari. Museveni's Uganda. Paradoxes of Power in a Hybrid Regime. Boulder, CO: Lynne Rienner, 2010.

Van Zyl, Paul. "Promoting Transitional Justice in Post-Conflict Societies." In Security Governance in Post-Conflict Peacebuilding, edited by A. Bryden and H. Hanggi, 209231. Geneva: DCAF, 2005.

Weiffen, Brigitte. "The forgotten factor - the impact of transitional justice on the development of the rule of law in processes of democratization." Zeitschrift für Vergleichende Politikwissenschaft 6, no. 2 (2012): 125-147.

Wiebelhaus-Brahm, Eric. "Promoting Accountability, Undermining Peace? Naming and Shaming in Transitional Justice Processes." In The Politics of Leverage in International Relations. Name, Shame, and Sanction, edited by H. Richard Friman, 86-104. Basingstoke: Palgrave Macmillan, 2015.

Wiebelhaus-Brahm, Eric. Truth Commissions and Transitional Societies: The Impact of Human Rights and Democracy. New York: Routledge, 2010.

Wierda, Marieke. "Comparison of the Legacy of the Special Court for Sierra Leone and the ICC Intervention in Uganda from a Practical Perspective." ASIL Proceedings 103 (2009): 218-222. 
